\title{
MATURITY MODEL TO MEASURE THE GOVERNMENT INSTITUTIONS OF INDONESIA (THE ENVIRONMENT BUREAUCRACY OF EDUCATION) IN THE IMPLEMENTATION OF E-GOVERNMENT
}

\author{
Bambang Saras Yulistiawan, Harjanto Prabowo, Dyah Budhiastuti and Ford Lumban Gaol \\ Bina Nusantara University, Jakarta, Indonesia \\ Received 2014-11-07; Revised 2014-11-12; Accepted 2014-12-23

\begin{abstract}
Implementation of e-Government are expected to be solution in the care system, but in the process will be a challenge that has a risk of failure. In this study will result in a maturity model that becomes the size of maturity/readiness of a government institution when it will make the process of e-Government implementation. With the results of this dissertation study is expected to have the readiness of government institutions and the risk of failure of the implementation process will be smaller.
\end{abstract}

Keywords: E-Government, Implementation, Maturity Model, Risk of Failure

\section{INTRODUCTION}

Government is a sector policy makers, administrative and public services such as (Presidential Decree No. 24 of 2010). The success of government services supported by many factors, one of the supporting factors is to implement e-Government (Presidential Instruction No. 3 of 2003). The Implementation of e-Government are expected to be solution as the service system, but the process will be a challenge that has a risk of failure. This paper will result in a maturity model that becomes the size of maturity or readiness of a government institution when the implementation of e-Government. It's also expected to minimize the risk of failure the implementation of e-Government.

\section{LITERATURES REVIEW}

\subsection{Maturity Model}

This paper discussed a maturity model for measuring the maturity and readiness of government agencies (the bureaucracy of education) in Indonesia. This study will used references on maturity models: Capability Maturity Model Integration (CMMI) and Maturity of Indonesian Software Industry or commonly known by its Indonesian CMM. The five maturity levels of the capability maturity model (GCMM, 2001).

\section{Capability Maturity Model Process Areas}

An incremental measurement scale based on a score ranging from 1 to 5 ; this scale is associated with the following generic qualitative model (Valdés et al., 2011):

Level 1: Initial Capability. The key domain area is addressed reactively and individually on a case by case basis; and there is evidence that it has been recognized and needs to be addressed

Level 2: Developing Capability. A regular intuitive pattern is followed in addressing the key domain area. Different people follow similar procedures to address the same tasks; however, there is neither formal training nor dissemination of procedures

Corresponding Author: Bambang Saras Yulistiawan, Bina Nusantara University, Jakarta, Indonesia 
Level 3: Defined Capability. Procedures related to the key domain area have been defined, documented and communicated; they are not sophisticated, but rather correspond to the formalization of existing practices. There is formal training to support initiatives related to the key area

Level 4: Managed Capability. It is possible to monitor and measure procedure fulfillment and compliance and to take action when the key domain area appears to work ineffectively and established standards and rules-related to the key area are applied throughout the organization

Level 5: Integrated Capability (Optimizing). Procedures related to the key domain area have reached the level of best practices and continuous improvements are applied. The key area is optimized through the use of ICT and it works in an integrated manner with other related areas

The evolving structure of the maturity levels suggests a roadmap for improvements, to be followed in moving up from lower levels of maturity up to level 5 (Optimizing) (Fig. 1-2). For illustrates the key domain areas and their minimum capability level required in each organizational maturity level Table 1.

\subsection{Critical Success Factors}

The implementation of e-Government will use some of the theories discussed on "The Study of Critical Success Factors for Implementation of e-Government" which will be the study of success factors on the implementation of e-Government (Darmawan, 2014).

Maturity model have CSF dimension Table 2. Maturity model has three dimensions: Maturity stage dimension, CSF dimension and assessment dimension (Niazi et al., 2003).

CSFs (Critical Success Factors) define the limited number of areas in which satisfactory results will ensure successful competitive performance for the individual, department or organization (Darmawan, 2014).

\subsection{IT Leadership}

The implementation of e-Government is strongly influenced by the IT Leadership (Fig 3-4). In many information technology companies give a lot of support and to transform its business growth. Likewise in governance and the role of IT Leadership is essential to make changes in management.

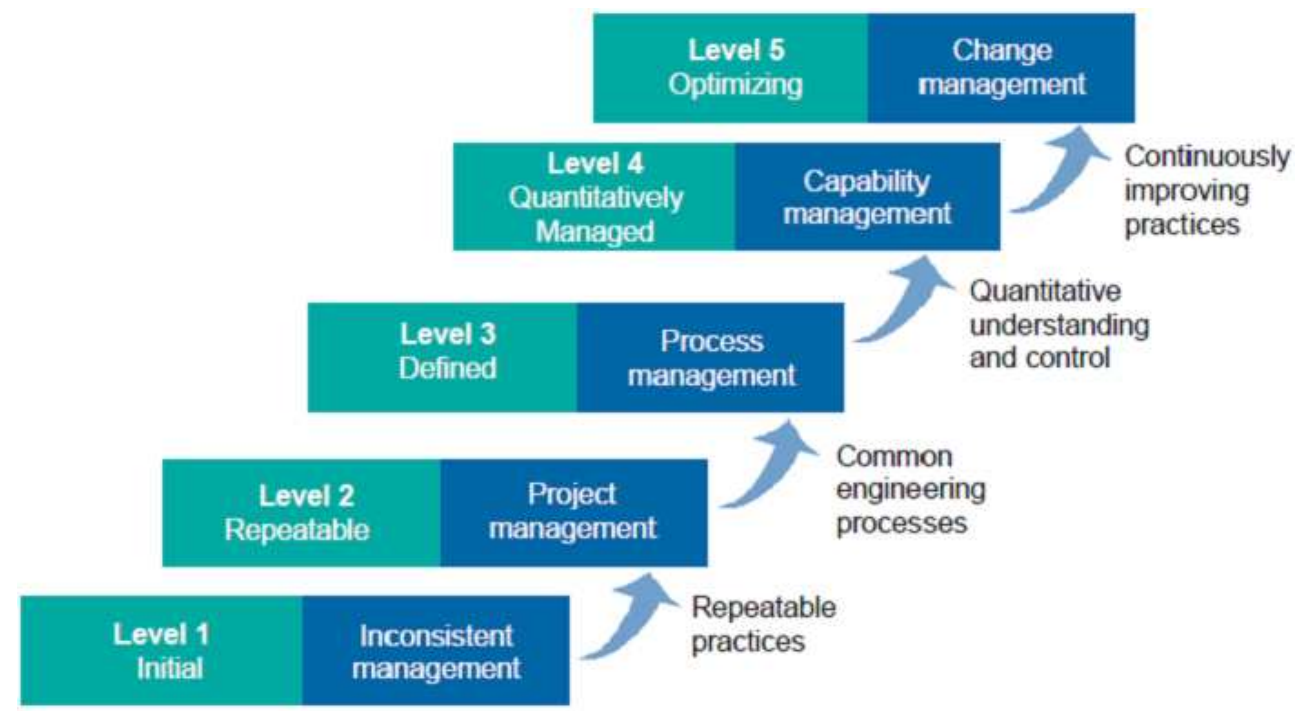

Source: TeraQuest

Fig. 1. Maturity level 


\begin{tabular}{|l|l|}
\hline \multicolumn{1}{|c|}{ Maturity Level } & \multicolumn{1}{|c|}{ Improvements Implemented } \\
\hline 5. Optimizing & $\begin{array}{l}\text { - Develop change infrastructure } \\
\text { - Evaluate and deploy improvements } \\
\text { - Eliminate causes of defects }\end{array}$ \\
\hline 4. Quantitatively Managed & $\begin{array}{l}\text { - Manage processes quantitatively } \\
\text { - Establish capability baselines }\end{array}$ \\
\hline 3. Defined & $\begin{array}{l}\text { - Establish improvement infrastructure } \\
\text { - Identify required software processes } \\
\text { - Define common software processes } \\
\text { - Deploy and manage processes } \\
\text { - Collect process-level data } \\
\text { - Provide organization-wide training } \\
\text { - Coordinate with non-software groups }\end{array}$ \\
\hline 2. Repeatable & $\begin{array}{l}\text { - Manage requirements } \\
\text { - Plan and track projects } \\
\text { - Manage suppliers } \\
\text { - Manage product configurations } \\
\text { - Measure projects } \\
\text { - Assist and assure policy compliance }\end{array}$ \\
\hline 1. Initial & \begin{tabular}{l} 
No required processes \\
\hline
\end{tabular} \\
\hline
\end{tabular}

Fig. 2. Process areas

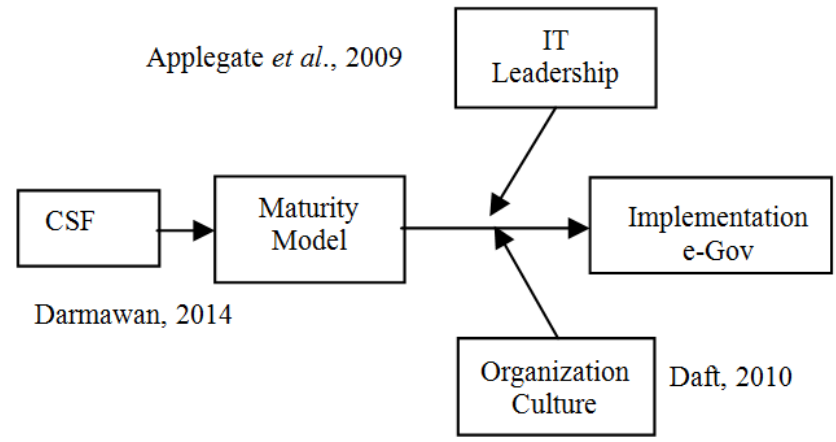

Fig. 3. Theoretical framework

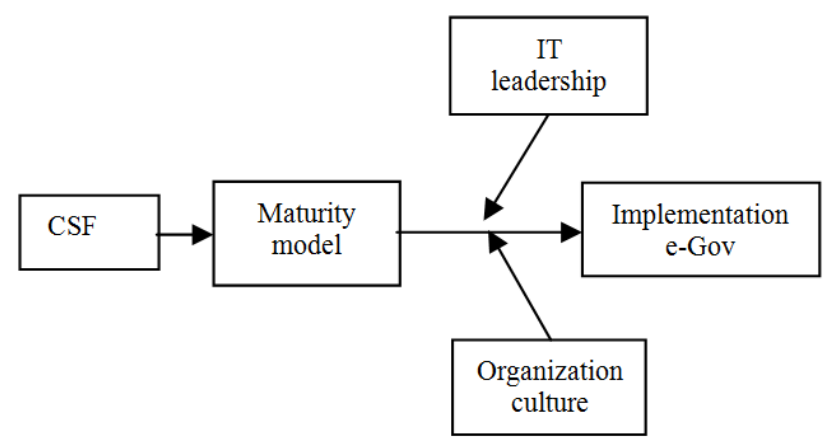

Fig. 4. Research model 
Table 1. Organizational maturity in terms of the capability of priority key domain areas

\begin{tabular}{|c|c|c|c|c|c|c|}
\hline \multirow[b]{3}{*}{ Leverage domain } & \multirow[b]{3}{*}{ Key domain area } & \multicolumn{5}{|c|}{ Organizational maturity levels } \\
\hline & & ML 1: & ML 2: & ML 3: & ML 4: & ML 5: \\
\hline & & Initial & Developing & Defined & Managed & Optimizing \\
\hline E-Government & Vision, Strategy and Policy & & 2 & 3 & 4 & 5 \\
\hline \multirow[t]{2}{*}{ Strategy } & Enterprise architecture strategy & & & & 3 & 4 \\
\hline & IT Management and Organization & & 2 & 3 & 4 & 5 \\
\hline IT & IT Architecture & & & 2 & 3 & 4 \\
\hline \multirow[t]{3}{*}{ Governance } & Portfolio and risk management & & 2 & 3 & 4 & 5 \\
\hline & IT Service delivery & & & 2 & 3 & 4 \\
\hline & Assets utilization & & & 2 & 3 & 4 \\
\hline \multirow[t]{6}{*}{ Process Management } & Business process management & & & 2 & 3 & 4 \\
\hline & Performance management & & & 2 & 3 & 4 \\
\hline & Services to citizen and business & & 2 & 3 & 4 & 5 \\
\hline & Interoperability & & 2 & 3 & 4 & 5 \\
\hline & Compliance & & 2 & 3 & 4 & 5 \\
\hline & Quality and security assurance & & & 3 & 3 & 4 \\
\hline \multirow[t]{4}{*}{ Organization and people } & Infrastructure and eGov tools & & 2 & 3 & 4 & 5 \\
\hline & Knowledge management & & & & 3 & 4 \\
\hline & Human capital & & 2 & 3 & 4 & 5 \\
\hline & Change management & & & & 3 & 4 \\
\hline
\end{tabular}

Table 2. Critical success factors for e-government implementation

\begin{tabular}{ll}
\hline No. & Critical success factor \\
\hline 1 & User and stakeholder involvement \\
2 & Good planning \\
3 & Using portal/Application \\
4 & Training \\
5 & Good system usability \\
6 & System campaign \\
7 & Prototype \\
8 & Good team skills and expertise \\
9 & Strong leadership \\
10 & Good coordination between all project participants \\
11 & Best practice consideration \\
12 & Enough funding \\
13 & Make bettet business process \\
14 & Supportive government policy \\
15 & Political support and strategy \\
16 & Good outsourcing strategy \\
17 & Supportive ICT infrastructure/service availability \\
18 & User/citizen computer/internet literacy \\
19 & Good and clear organizational structure \\
20 & International support \\
21 & System security \\
22 & Legal framework \\
23 & Monitoring and evaluation \\
24 & Good partnership with other institution \\
25 & Good change management \\
26 & Supportive cultural environment \\
27 & Good system modeling \\
28 & Deal with bureaucratic processes \\
29 & Citizen relationship management \\
30 & Sop management support \\
31 & Good project management \\
32 & \\
33 & Good system quality \\
\hline &
\end{tabular}

\subsection{Organization Culture}

The implementation of e-Government is also greatly influenced by organizational culture, especially the culture of work. In Many information technology companies give a lot of support, and transform their business for growth. Likewise in government, IT Leadership role is essential for change management (Deborah, 2009)

\section{PROBLEM INDENTIFICATION AND STATEMENT}

This paper presents the author's issues regarding the implementation of e-Government, especially studies related to the size of the model that will provide the measurement of maturity (maturity models). How this will Maturity Model can be a measure of the maturity of government institution (the bureaucracy of education) in Indonesia to the implementation of e-Government. In the implementation of e-Government does IT Leadership and Organizational Culture has a role and influence in the process?

\section{THEORETICAL FRAMEWORK}

The implementation of e-Government in Indonesia is solution to improve government services to the general public with a performance-based electronics for effectiveness and efficiency. From the literature review made a research frame as follows. 
This paper presents two approaches they are Critical Success Factor and Maturity Models that can be used for the implementation of e-Government in Indonesia.

\section{HYPOTHESES AND PROPOSED RESEARCH MODEL}

From the theoritical frame of thought which there are several hypotheses:

H-1: CSF impacts on Maturity Model

H-2: Maturity Model impacts on Implementation eGovernment

H-3: There is relationship between IT Leadership and Implementation e-Government

$\mathrm{H}-4$ : There is relationship between Organization Culture and Implementation e-Government

\section{RESEARCH METHODS}

This paper will conduct a survey process to all the factors supporting success factors (critical success factors) in implementation of e-Government. Having determined that these factors can be adapted to existing conditions in Indonesia, especially needed in the governance environment. The research will see for a maturity model to measure the maturity or readiness of the implementation of e-Government. The author's will explain that there's a relationship between the Critical Success Factors (CSFs) with a maturity model to be created.

The first test for descriptive hypotheses, the formulation of the hypothesis is:

- IT Leadership affects the maturity value of a government institution for implementation of eGovernment

- Organizational Culture Work, especially the culture of work also affects the value of the maturity of a government institution for implementation of eGovernment

\section{ACKNOWLEDGEMENT}

I am using this opportunity to express my gratitude to everyone who supported me throughout of this paper. I am thankful for their aspiring guidance, invaluably constructive criticism and friendly advice. I am sincerely grateful to them for sharing and illuminating views on a number of issues related to this paper. I express my warm thanks to Mr. Kastum for his support and guidance at The Ministry of Education and Culture. I would also like to thank my project external guide to all staff in research and community service at BINUS University.

\section{ADDITIONAL INFORMATION}

\subsection{Funding Information}

This paper cannot be completed without funding and support from Doctorate Program of Bina Nusantara University and Ministry of Education and Culture.

\subsection{Author's Contributions}

Bambang Saras Yulistiawan: Preparation and developing the manuscript.

Harjanto Prabowo: Reviewing the hypotheses and research model.

Dyah Budihastuti: Reviewing the literature review and theoretical framework

Ford Lumban Gaol: Reviewing all of the manuscript to be proper for a publication.

\subsection{Ethics}

Any ethical issues or in case of problems after the publication of this paper will be the responsibility of the authors.

\section{REFERENCES}

Darmawan, N., 2014. The critical success factors study for e-government implementation. Int. J. Comput. Applic. DOI: 10.5120/15716-4588

Niazi, M., D. Wilson and D. Zowghi 2003. A maturity model for the implementation of software process improvement: an empirical study. J. Syst. Software, 74: 155-172. DOI: 10.1016/j.jss.2003.10.017

Valdés, G., M. Solar, H. Astudillo, M. Iribarren and G. Concha et al., 2011, Conception, development and implementation of an e-government maturity model in public agencies. Gove. Inform. Q., 28: 176-187. DOI: $10.1016 /$ j.giq.2010.04.007 